\title{
Spiritualiteit - 'n perspektief uit die Ou Testament
}

\author{
S.D. (Fanie) Snyman \\ Departement Ou Testament \\ Universiteit van die Vrystaat \\ BLOEMFONTEIN
}

\begin{abstract}
Spirituality - a perspective from the Old Testament

Spirituality is defined as coram Deo, that is, living in the presence of God. In this article it is argued that within the South African context, the Old Testamemt is not given due regard in the scholarly debate on spirituality. The foundation of an Old Testament spirituality is God revealing his name in Exodus 3:14-15 as the ever-present God. Following the tripartite division of the Old Testament it is argued that the Torah can be seen as a call to obedience within covenantal structures. The prophets can be seen as proclaimers of God's Word. Jeremiah and Habakuk are examples of prophets who were not at ease with God and his actions. The doxologies found in prophetic literature are also important aspects of an Old Testament spirituality. The contribution of the Ketubim to the theme of spirituality can be summarised by the concepts of prayer and life. This preliminary investigation into the contribution the Old Testament can make on the issue of spirituality shows that much can be gained by taking the Old Testament into full account when reflecting on spirituality.
\end{abstract}

\section{Inleiding}

Die tema van spiritualiteit is 'n gewilde en belangrike tema in kerklike en teologiese gesprekke die afgelope paar jaar in veral Suid-Afrika. Jonker (1989: 288) beskryf dit as 'n begrip wat "vandag hoog in die mode" is. Du Toit (1993: 28) praat van 'n behoefte aan ware spiritualiteit en 'n gevolglike ontploffmg van populêre en wetenskaplike publikasies oor die onderwerp van spiritualiteit. Dit is 'n onderwerp wat met name ook vanuit gereformeerde hoek druk gediskusseer word (Strauss, 1987:20-38; Smit, 1988:182-193; Smit, 1989:83-94; Nicol, 1989:48-63; Jonker, 1989:288-299).

\subsection{Die term spiritualiteit}

Dit is uit die literatuur oor die onderwerp nie sonder meer duidelik wat met die term spiritualiteit bedoel word nie. Verwys die begrip na vroomheid, 'n soort piëtisme, godsdienstigheid, toewyding, godsaligheid (na aanleiding van 1 Tim. 4: 7), innerlike belewing, die geestelike lewe van 'n gelowige? Smit (1989:85) wys daarop dat die begrip in die loop van die geskiedenis telkens van betekenis 
verander het. 'n Verskeidenheid definisies en omskrywings is daarom al gegee om die term mee te omskryf. Louw (1989:11) en ook Smit (1989:85) gee 'n reeks definisies uit resente literatuur oor die ondenwerp waarin elemente soos gebed, gebed en lewe, die bewussyn van 'n transendente dimensie van ons bestaan, die integrasie van geloofsinhoude by die konkrete praxis van elke dag, spiritualiteit as hoop, die verhouding tot God, aspekte van die verskillende omskrywings van die begrip vorm. Jonker (1989:288) verwys ook na die probleem en verstaan die term spiritualiteit as die beleweniskant, ervaringskant of subjektiewe kant van die religie wat weergegee kan word met geloofsbelewing, geloofservaring, geloofsbeoefening en geloofspraktyk. De Jongh van Arkel (1989:19-20 verstaan spiritualiteit as Christelike lewensoriëntasie. Du Toit (1993:28) vind dit ook nodig om 'n omskrywing van die begrip te gee. Volgens hom is spiritualiteit "'n lewenskwaliteit wat hom eerstens in 'n bepaalde geestelike ingesteldheid en diepgang manifesteer, wat hom tweedens in kenmerkende geestelik-godsdienstige gestaltegewings uitdruk en derdens 'n spesifieke stempel op die betrokkenes se lewenstyl (etiek) afdruk" (Du Toit, 1993:28).

Vir die doeleindes van dié artikel word spiritualiteit verstaan as coram Deo - 'n lewe voor die aangesig of in teenwoordigheid van God. Wanneer die saak vanuit die hoek van die Ou Testament bekyk word, is dit die formulering wat die naaste aan 'n Ou-Testamentiese verstaan van spiritualiteit kom.

\subsection{Probleemstelling en metodologiese opmerkings}

Die tema van spiritualiteit is al vanuit 'n verskeidenheid teologiese dissiplines benader. 'n Oorsig oor spiritualiteit sluit gewoonlik 'n (kerk-)historiese dimensie in waarin gewys word op die verskynsel van spiritualiteit in die gang van die geskiedenis voor en na die Reformasie en ook hoe spiritualiteit op eie bodem hier in Suid-Afrika histories vertoon het (Strauss, 1987:21-28; Nicol, 1989:51-57; Jonker, 1989:292). Spiritualiteit word ook vanuit die hoek van die dogmatiek beskryf (Smit, 1988:182-193; Smit, 1989:83-94; Jonker, 1989:288-299). Vanuit die dissipline van die Praktiese Teologie is daar ook al aandag aan die saak gegee. So word 'n hele nommer van die tydskrif Praktiese Teologie in SuidAfrika in 1989 gewy aan spiritualiteit (Louw, 1989:1-17; De Jongh van Arkel, 1989:18-30; Theron, 1989:31-47; Pieterse, 1989:48-56).

Die probleem wat in hierdie artikel aandag kry, is die bydrae van die Ou Testament tot die debat oor spiritualiteit. Watter bydrae kan die Ou Testament lewer tot die debat oor spiritualiteit? Die spesifieke bydrae van die Ou Testament is minstens in die Suid-Afrikaanse debat nog nie na wense in berekening gebring nie. Louw (1989:1) praat van spiritualiteit as Bybelse vroomheid maar hanteer dan die begrip eusebeia - 'n Nuwe-Testamentiese begrip - as die begrip wat "die konsep van toewyding, vroomheid of godsvrug die beste" beskryf (Louw, 
1989:7) met weinig aandag aan die Ou Testament. Du Toit (1993:28) gebnuik die tern Bybelse spiritualiteit waarmee 'n Ou- sowel as Nuwe-Testamentiese blikpunt veronderstel word. Alhoewel meer aandag aan die Ou Testament gegee word en daar ook geslaag word om belangrike aspekte van 'n tipies OuTestamentiese spiritualiteit bloot te lê, word 'n groot deel van die artikel afgestaan aan 'n Nuwe-Testamentiese perspektief op spiritualiteit.

Om 'n onderwerp soos dié van spiritualiteit in die Ou Testament te hanteer is in meer as een opsig ietwat van 'n verleentheid. Die Ou Testament is 'n omvangryke boek met soveel perspektiewe dat 'n mens amper nie kans sien om dit te waag om voor te gee dat dit nou dié perspektief van die Ou Testament op 'n bepaalde saak is nie. Metodologies gesproke, moes daar dus noodgedwonge selektief te werk gegaan word deur grepe uit die Ou Testament te neem wat relevant vir die tema van spiritualiteit is. Elk van die drie dele van die Ou Testament word aan die woord gestel: die Tora, die Profete en die Geskrifte. Waar toepaslik, is bepaalde voorbeeldtekste gekies om 'n saak uit die besondere korpus (Tora, Profete of Geskrifte) te illustreer. Die rede waarom hierdie metodologiese weg gekies is, is om enersyds te waak teen vae veralgemenings en om aan die ander kant eksegeties aan 'n teks gekoppel te bly. 'n Volledige eksegese van tekste word nie gegee nie, maar die teologiese interpretasie van die tersaaklike tekste berus op 'n eksegese van die tekste waar sowel die strukturele as die historiese dimensies van die tekste aandag gekry het. Uiteraard word nie alles wat die Ou Testament oor spiritualiteit te sê het, aangeraak nie - gewoon omdat dit binne die omvang van 'n artikel van dié aard onmoontlik sou wees.

\section{Die grond van 'n Ou-Testamentiese spiritualiteit}

Wat is die grond, die diepste motief van 'n Ou-Testamentiese spiritualiteit? Die grond van 'n Ou-Testamentiese spiritualiteit is God. Daarmee word bedoel dat God in die Ou Testament in verhouding tree met mense. Met name kan die grond van spiritualiteit in die Ou Testament gevind word in die openbaring van God se Naam aan Moses in Eksodus 3:14-15.

Wat beteken die Naam van die Here soos wat Hy Hom hier aan Moses bekendmaak? Wat beteken dit dat die Here sê: "Ek is wat Ek is"? Daar is haas nie 'n teologie van die Ou Testament wat die openbaring van die Naam Jahwe in Eksodus 3:14-15 nie uitvoerig bespreek nie en ruimte ontbreek om volledig op dié problematiek in te gaan (vergelyk byvoorbeeld die Ou Testament-teologieë van Eichrodt (1975a), Von Rad (1975b), Zimmerli (1978), Childs (1987), Preuss (1991) - om net enkeles te noem - asook die verskillende kommentare op Eksodus). Die volgende woorde wat in Eksodus 3:14 gebruik word אהיח אשר

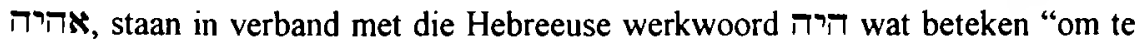
wees". Met diè bekendmaking wil die Here dus sê: Ek is die altyd teenwoordige 
God. Eichrodt (1975:189) se verklaring van die Naan gee hy weer met 'n vertaling van "Hy is", "Hy bestaan", "Hy is teenwoordig" en Von Rad (1975a:180) verstaan ook die Naam in terme van die teenwoordigheid van Jahwe: "... the היה is to be understood in the sense of 'being present', 'being there'...". Vir Vriezen (1966:372) gaan dit ook om "het persoonlijk aanwezig zijn" van God in die openbaring van die naam Jahwe. Alhoewel Preuss (1991:161) ontken dat die uitdrukking handel oor die bestaan van God aangesien die bestaan van God nie in die $\mathrm{Ou}$ Testament bevraagteken word nie, gaan dit vir hom tog ook oor die Mit-Sein van God in die ervarings van Israel. In die onlangse verlede het SiebertHommes (1996:59-67) die saak weer beredeneer en tot die gevolgtrekking gekom dat dit in die teksgedeelte handel oor die teenwoordigheid van God.

As die Here Hom aan Moses bekend maak as "Ek is wat Ek is", dan word hier iets wesenliks van God gesê. As Moses vra na die Naam van God, vra Hy eintlik na die wese van God: Here, hoe is U nou eintlik? Wie is U? Wat kan ek vir die mense gaan vertel van U? God se antwoord op die vraag is "Ek is wat Ek is", en daarmee sê God: Ek is die altyd teenwoordige God.

Dat God die teenwoordige God is, loop soos 'n goue draad deur die hele Bybel. As die Israeliete byvoorbeeld uit Egipte trek, is God teenwoordig in die wolkkolom en die vuurkolom. Na die goue-kalf-episode is dit die teenwoordigheid van Jahwe wat in gedrang is en dan moet nuwe maatreëls getref word om Jahwe se teenwoordigheid te verseker (Eks. 32-34). Later as die Israeliete hulleself gevestig het in die land, word 'n tempel vir die Here gebou en daar is $\mathrm{Hy}$ teenwoordig. Wanneer God later profete stuur om met sy volk te praat, dan is Hy teenwoordig in sy Woord.

Die teologiese lyn van die voortdurende teenwoordigheid van Jahwe word ook in die Nuwe Testament voortgesit. In die Nuwe Testament sê die engel vir Josef in Matteus 1 hulle sal Hom, dit is Jesus, Immanuel noem en dit beteken: God met ons. In die Johannes-evangelie maak Jesus sy bekende "Ek is"-uitsprake. Ek is die goeie Herder, Ek is die ingang vir die skape, Ek is die brood van die lewe, Ek is die lig vir die wêreld, Ek is die opstanding en die lewe, Ek is die ware wingerdstok. Hierdie "Ek is"-uitsprake is niks anders as 'n teruggrype van Jesus op Eksodus 3 nie. Jesus is dus God, teenwoordig op aarde. Wanneer Jesus Christus na sy kruisiging opvaar hemel toe sê Hy kort voor sy hemelvaart vir die dissipels: "Ek is by julle al die dae tot die voleinding van die wêreld" (Matt. 28:20). Wanneer die Heilige Gees uitgestort word, kom woon die Heilige Gees in ons. Dit is die nuwe manier waarop God nou teenwoordig is. God is teenwoordig deur sy Heilige Gees.

'n Ou-Testamentiese spiritualiteit lê dus in die oortuiging dat die lewe geleef word in die voortdurende teenwoordigheid van God. Hierdie aksent word ook in die Nuwe Testament gekontinueer. 


\section{Die Tora: gehoorsaamheid as verbondshandeling}

Die lewe in die teenwoordigheid van God word in die Tora of Pentateug gestruktureer as 'n lewe binne die verbond wat God met sy volk en met mense gesluit het (Eks. 19). Verbond is 'n begrip wat wil sê God kom na ons toe, God kom tot by ons, Hy tree in 'n naby verhouding met mense, Hy verbind Homself kontraktueel met sy volk. Du Toit (1993:31-32) praat in dié verband van 'n relasionele raamwerk waarbinne die lewensgemeenskap tussen God en mens hom afspeel.

Binne die verbond geld bepalings wat in detail in die Tora uiteengesit word (vergelyk byvoorbeeld Eks. 20-23; die boek Deuteronomium). Die detail van dié bepalings sê dat daar nie 'n deel van die lewe is wat geleef kan word buite die teenwoordigheid van God nie. Dit is ook opvallend dat groot dele van die detailbepalings wat gegee word nie kultiese reelings is nie, maar doodgewoon praktiese of sekulêre sake verteenwoordig. In die Dekaloog handel ses van die tien gebooie oor sake wat op die vlak van menseverhoudinge lê. Die belangrikste van die bepalings word in die boek Deuteronomium gevind. In Deuteronomium word gehandel oor sake soos die verdwaalde bees van 'n buurman (Deut. 22:1), die hantering van slawe (Deut. 15:12-18) en billike optrede teenoor ander (Deut. 24). Die belangrikste van die bepalings in die boek Deuteronomium is ongetwyfeld die bepalings oor die liefde vir God en die naaste.

Die appèl van Deuteronomium is om gehoorsaam te wees aan die verskillende bepalings van die verbond. Omdat Jahwe al sy heilsdade vir sy volk laat realiseer het (die verlossing uit Egipte, die verbondsluiting by Sinai, die gawe van die land, die Israeliete se verkiesing tot volk van God) moet hulle Hom liefhê en gehoorsaam. Klem word gelê op die innerlike ingesteldheid van die volk en die hartlike aanvaarding van die gebooie as gids vir die lewe. $\mathrm{Al}$ die verskillende gebooie is maar net 'n nadere toeligting van die sentrale gebod van die liefde vir God (Von Rad, 1975a:225-226). Dankbaarheid speel ook 'n belangrike rol: 'n mens is gehoorsaam aan die gebooie as uitdrukking van jou dankbaarheid teenoor die Here vir die verlossing wat jy ervaar het (Kloppers, 1988:76-83).

Die Tora wil sê gelowiges leef in die teenwoordigheid van God as mense wat dankbaar is vir die verlossing. Hierdie dankbaarheid kom tot openbaring op 'n wyse wat in die alledaagse lewe gesien kan word. God word dus nie net kulties gedien nie; Hy word veral ook prakties gedien. Die spiritualiteit van die $\mathrm{Ou}$ Testament is dus nie slegs 'n "geestelike" aangeleentheid waarin daar eensydig gefokus word op die verhouding met God nie. Ou-Testamentiese spiritualiteit is eerder ' $n$ baie konkrete aangeleentheid wat in die praktyk van die alledaagse lewe gestalte moet kry juis omdat die lewe geleef word in die teenwoordigheid van God en uit dankbaarheid vir die verlossing uit Egipte. 


\section{Die profete: verkondigers, worstelaars en verwonderaars}

Die profete is primêr verkondigers van die wil van God. Hierdie feit blyk duidelik as die roepingsberigte van die profete nagegaan word (vgl. Jer. 1:9; Eseg. 3:1; Jes. 6:8-9; Amos 3:1-8). Die gebruik van die sogenaamde boodskappersformule onderstreep die feit verder. Profete word geroep om te sê: "So sê die Here!" Wat die profete moes doen, was om te put uit die heilstradisies van die verlede, dit te aktualiseer vir die hede se lewe voor God en ook 'n perspektief op die toekoms te ontsluit (Le Roux, 1986:126-144). Die inhoud van die boodskap van die profete sou beskryf kon word as 'n terugroep (bekering) na 'n lewe in die bewussyn van die teenwoordigheid van God (Sef. 2:3; Hag. 2:14; Sag. 1:3). Soos wat die Tora ook handel oor gewone, nie-kultiese sake, spreek die profete hulle ook uit oor veral nie-kultiese sake, sake wat op die gebied van menseverhoudinge en sosiale geregtigheid lê. Daar is dus by die profete aan die een kant 'n identifikasie met die konkrete werklikheid van die wêreld, maar tegelykertyd 'n radikale toewyding aan God.

Om profeet van die Here te wees beteken tegelykertyd ook om in 'n intieme verhouding met God te leef - in so 'n mate dat 'n mens selfs sou kon sê dat die profete al hoe meer los van hulleself en hulle eie persoonlike voorkeure word om al hoe meer ingetrek te word by die emosies van God (Von Rad, 1975b:63). God moet in mense se lewens deursigtig word. Om in so ' $n$ verhouding met die Here te leef is deel van die spiritualiteit van die Ou Testament.

Die profete was nie net verkondigers nie. Hulle was ook worstelaars met God. Jeremia en Habakuk is twee voorbeelde wat relevant is vir die tema van spiritualiteit. Om profeet van die Here te wees het nie ' $n$ probleemlose verhouding met die Here geïmpliseer nie. Die belydenisse van die profeet Jeremia (11:18-23; 12:1-6; 15:10-14; 15:15-21; 17:14-18; 18:18-23; 20:7-13; 20:14-18) gee ' $\mathrm{n}$ aangrypende $\mathrm{kyk}$ in die hart en belewenisse van iemand wat die opdrag het om profeet van die Here te wees. Die belydenisse van Jeremia het die intensiewe aandag van navorsers geniet (Ittman, 1981 en Diamond, 1987).

In die boek Habakuk vra die profeet Habakuk vrae an God en die Here antwoord mettertyd ook op die vrae van Habakuk'. Die antwoord wat Habakuk op sy vrae kry, is 'n vreemde antwoord; dit is om die waarheid te sê 'n onverstaanbare, 'n onbegryplike antwoord. Miskien is dit juis iets wat geleer kan word uit die boek Habakuk: die manier waarop God werk, is nie altyd verstaanbaar nie. 'n Deel van die Ou-Testamentiese spiritualiteit is om te worstel met God oor die onbegryplikhede van sy optrede in die lewe van 'n indiwidu (soos by Jeremia) en die wêreld (soos in die boek Habakuk). Die Ou-Testamentiese

1 Vir 'n eksegetiese beredenering van die tersaaklike teksgedecltes uit Habakkuk vergelyk Snyman (1996:68-86), Haak (1992) en Prinsloo (1989). 
spiritualiteit werk met die oortuiging dat menslike insig beperk is. Mense het eenvoudig nie die vermoè om alles wat gebeur binne die groter raamwerk van God te sien nie. God se antwoord op ons vrae is daarom dikwels vreemd en onverstaanbaar.

Van gelowiges word verwag om geduld aan die dag te lê, om te wag vir die tyd wat God bestem het. Dit is opmerklik hoe 'n belangrike rol "wag" speel in die boek Habakuk (Hab. 2:1, 2:3, 3:16). Om te wag op die Here is deel van die OuTestamentiese spiritualiteit. Hoe gebeur dit? Hoe kry 'n mens dit reg om te wag op die Here en loe kom 'n mens soos Habakuk tot rus in God ten spyte van al die onreg en ongelukkigheid en onregverdigheid en pyn en swaarkry van die lewe? Die profete van die Ou Testament sê daar is nie kitsoplossings vir dié soort van vrae nie. Habakuk het sy vrae aan God gestel en die antwoorde is ook waarskynlik nie binne 'n uur of twee gegee nie. Daar het tyd verloop tussen die gesprekke in die boek Habakuk, maar hy het begin om met God in gesprek te tree. Dit is in gesprek met God wat 'n mens tot rus kom oor vrae wat pla.

Die profete se boodskap uit luulle woorde en wat ons weet uit hulle persoonlike lewens sê eintlik dat mense in 'n verhouding met God en in gehoorsaamheid (die aksent van die Tora) aan Hom moet leef - 'n gehoorsaamheid wat gesien kan word in dinge wat mense doen. Dit is 'n verhouding met God en gehoorsaamheid aan Hom wat sin en rigting en betekenis aan die lewe gee. Dit is immers 'n mens se verhouding met die Here wat help om met die swaar, onverstaanbare en teenstrydige dinge van die lewe saam te leef.

Mense wat klaar so lewe, mense wat lewe in ' $n$ verhouding met die Here en met hulle naaste - 'n lewenswyse wat 'n mens as "reg" sou kon bestempel (Hab. 2:4) - sulke mense word aangespoor om getrou te bly, om aan te hou glo, om erns te maak met gehoorsaamheid aan die Here, om voort te gaan om gelowige te wees. Daar moet 'n geloofstaaiheid by gelowiges wees, 'n uithouvermoë. Hulle is die mense wat dit reg kry om sinvol te lewe. Die spiritualiteit van die Ou Testament is dus nie 'n geestelike utopia waar 'n mens van een geestelike hoogtepunt na 'n volgende meegevoer word nie. Spiritualiteit in die Ou Testament is 'n spiritualiteit waar die lewe geleef word in die teenwoordigheid van God al spreek die werklikhcid met sy onbegryplikhede daarteen.

Vir Habakuk het dit gewerk. Die boek Habakuk eindig met 'n gebed wat eintlik 'n lied is op die grootheid en werk van God. Habakuk sien God in sy gebed. Hy sien die grootheid en die mag van God, maar Hy sien ook God wat naby aan mense kom in die verbond. Spiritualiteit in die Ou Testament beteken om te leef soos mense wat God sien. Mense wat God sien, sien hulle probleme anders. Sonder God kan die dinge wat bang en onseker maak, die dinge waaroor mense bekommerd is, oorweldigend wees, dit kan te groot wees om te hanteer. Met God verdwyn probleme nie, dit lyk egter anders. Met God kom probleme, die 
onbegryplike en soms teenstrydige dinge in perspektief omdat ons dit anders sien. Met God word probleme hanteerbaar.

Terwyl die eerste gedeelte van Habakuk 3 handel oor die ontsagwekkende grootheid van God, van sy mag en dade in die geskiedenis, handel die laaste gedeelte van Habakuk 3 oor die klein wêreldjie van die alledaagse bestaan van die Israelitiese kleinboer. Habakuk 3:17-19 praat van 'n oes wat dreig om te misluk, van beeste en skape wat nie meer in 'n kraal is nie. Wat sê dit? Binne die groot patroon van God se mag, sy dade in die geskiedenis, van sy optrede, 'n patroon wat 'n mens ook nie altyd eers mooi verstaan nie, kry my klein bestaan sin, het ek die moed om te lewe.

Partykeer moet 'n mens iets glo om dit te kan sien. Dit is veral waar van God. Om God te kan sien, moet 'n mens glo. Gelowiges in die Ou Testament en hedendaagse gelowiges behoort nie te sê "sien is glo" nie, maar "glo is sien". Omdat ek in God glo, sien ek Hom ook.

Profete in die Ou Testament is verseker dat God luister (Mal. 3:16). Dit is opmerklik hoedat God telkens luister na Jeremia, Habakuk en ander profete sonder 'n woord van verwyt. God luister simpatiek en liefdevol.

Die profete is nie net verkondigers en worstelaars nie, hulle is ook verwonderaars. Telkens in die doksologieë in die profetiese literatuur is die profete in verwondering voor die misterie van God. Om in verwondering te wees voor die misterie van God wat nooit heeltemal ten volle begryp of verklaar kan word nie is ook deel van die spiritualiteit van die Ou Testament.

\section{Die Geskrifte: gebed en lewe}

Die eerste boek in die deel wat bekend staan as die Geskrifte in die $\mathrm{Ou}$ Testament is die boek Psalms. Die Psalms is gebede waarin gelowiges hulle klag en lof voor God uitspreek met 'n verstommende eerlikheid. Gebed is 'n wesenlike deel van die Ou-Testamentiese spiritualiteit. Die voorbeeldteks wat hier sinvol kan wees, is Psalm 42/432 omdat die tema van die teenwoordigheid van God hier ter sprake kom maar dan as 'n ervaring van die afwesigheid van God (Odendaal \& Smit, 1988:101).

Wanneer 'n mens dié psalm lees ${ }^{3}$, is dit duidelik dat die digter se huidige situasie nie gunstig is nie. Vers 4 lui: "Dag en nag is ek in trane", en in vers 8 staan

2 Dat Psalm 42 en 43 as 'n eenheid gesien moet word, word wyd deur kommentatore aanvaar. Vergelyk byvoorbeeld die kommentare van Kraus (1972:318), Weiser (1975: 347) en Dahood (1974:255).

3 Ruimte ontbreek om 'n volledige eksegese van die psalm te gec. Vergelyk egter Snyman (1986:45-52) en Odendaal en Smit (1988.96-112) vir 'n volledige eksegese. 
daar: "U het golf op golf oor my laat slaan". Die eerste deel van die refreinvers in die psalm sê ook iets van die digter se situasie: "Waarom is ek so in vertwyfeling en waarom kerm ek so?" Uit die psalm blyk dit dat die digter homself ver van God af gevoel het. Hy het die teenwoordigheid van God in sy lewe gemis - vergelyk byvoorbeeld vers 10: "Ek wil vir God sê: My Rots, waarom het U iny vergeet?" Volgens vers 7 was die digter in die omgewing van die Jordaangebied en die Hermonberg, ver van Jerusalem en Jerusalem was die plek waar die tempel was. Die tempel was in die denkwêreld van daardie tyd die plek waar God veral teenwoordig was.

Dit was ook die vraag wat die mense rondom die digter van dié psalm begin vra het: in vers 4 staan dit in soveel woorde - waar is jou God? Ons sien dan so min van jou God se teenwoordigheid!

Watter antwoord bied dié psalm op die dilemma waarin die digter (en so baie ander gelowiges) hulle bevind? Hierdie psalm sê: Kyk vanuit jou huidige ongunstige, slegte situasie na 'n punt in jou verlede waar jy 'n ontmoeting met God gehad het. Dit sal jou krag gee vir die krisis van die situasie van nou. 'n Ontmoeting met God in die verlede gee krag vir die krisis van die hede. Hierdie digter kon terugdink aan 'n ontmoeting met God wat hy in die verlede met Hom gehad het. Hy verwys na 'n ontmoeting met God in die verlede wat hy in die erediens gehad het. In vers 5 sê hy: "Ek dink daaraan hoe ek opgetrek het na die woonplek van God, voor' 'n skare uit na sy huis geloop het met gejuig en lofsang - 'n skare wat feesvier". Hier word dus nie in die eerste plek verwys na 'n mistieke ontmoeting met God nie. Die digter dink aan sy laaste erediens. Die erediens kan die plek wees waar mense ' $n$ ontmoeting met God beleef as 'n werklikheid. Spiritualiteit in die Ou Testament word dus nie net indiwidueel beleef nie, spiritualiteit word veral korporatief in die gemeenskap van die heiliges beleef.

Die belewing van God se teenwoordigheid in die erediens is 'n bevestiging van God se teenwoordigheid in die hele lewe. Gelowiges het net nodig om daaraan herinner te word want 'n mens vergeet dit so maklik. Die erediens is daar om gelowiges te herinner aan God se voortdurende teenwoordigheid.

Iemand het by geleentheid gesê om die lewe met God te leef is al erg genoeg, maar sonder Hom is dit eenvoudig onvoorstelbaar. Die digter van Psalm 42 het dieselfde oortuiging. In vers 2 sê hy hy smag na God soos wat 'n wildsbok smag na water. Soos 'n wildsbok vir sy bestaan afhanklik is van water, so is mense vir hulle bestaan afhanklik van God. Sonder God kan die digter en gelowiges in die algemeen nie klaarkom nie.

Die Wysheidsliteratuur (Spreuke, Job, Prediker, enkele Psalms wat Wysheidspsalms genoem kan word) maak 'n wesenlike deel uit van die kanon maar was 
tog vir lank óf geïgnoreer óf is beskou as ' $n$ randverskynsel in die Ou Testament wat nie aandag verdien nie (Perdue, 1994:20 e.v.). Wysheid kan beskryf word as 'n nadenkende manier van kyk na die werklikheid waarmee Oud-Oosterlinge hulle in die wêreld probeer oriënteer het (Loader, 1986:103). Wysheid kan ook bestempel word as riglyne vir die bemeestering van die lewenskuns. Die lewe is gekompliseerd, dit is nie altyd maklik om die regte en beste besluit vir 'n bepaalde situasie te maak nie; daarom is Spreuke daar on gelowiges te help om wys te wees in die lewe. Die voorbeeldteks wat hier gekies word, is Spreuke 4:23.

Wat lê agter die keuses wat ons maak? Dit is in dié verband dat die wysheidsliteratuur van die Ou Testament ons help. Spreuke 4:23 sê 'n mens se keuses word bepaal deur dit wat in jou hart omgaan: "Wees veral versigtig met wat in jou hart omgaan, want dit bepaal jou hele lewe" - (NAV)

Wat word bedoel met 'n mens se hart in die Bybelse sin van die woord? Hart kan doodgewoon die pomporgaan in jou liggaam aandui. In Jeremia 4:19 praat Jeremia byvoorbeeld van sy hart wat wild bons in hom. Baie mense dink dat met die hart van die mens die setel van sy emosies, die gevoelslewe van 'n mens bedoel word. So byvoorbeeld dink party mense dat om tot bekering te kom 'n saak van die hart is, dit is 'n emosionele saak, dit is iets wat my gevoel raak. Dit is waar, maar dit ook net halfpad waar.

In die meeste gevalle in die Bybe! word met die begrip "hart" 'n mens se denke, sy verstand, sy gedagtes, sy wil bedoel. Dit geld ook vir Spreuke 4:23 (McKane, 1977:310). Spreuke 4:23 sê dus 'n mens moet let op die gedagtes wat jy dink, want wat jy dink, bepaal jou hele lewe.

Dit beteken dat daar by elke mens - bewustelik of onbewustelik - 'n stel waardes geld wat veroorsaak dat jy bepaalde besluite neem, besluite wat jou lewe radikaal beinvloed. Agter die keuses wat mense maak, is daar beginsels, waardes, oortuigings wat ons rig om besluite te neem soos wat ons hulle neem. Dit is die rede waarom 'n mens goed voel oor die waardes wat in sekere TV-programme geprojekteer word en ongemaklik voel oor die waardes wat in ander progamme geprojekteer word.

Die jaar 1996 sal waarskynlik in die toekoms onthou word as die jaar van 'n nuwe grondwet van Suid-Afrika. 'n Grondwet van 'n land is die belangrikste wet van al die wette wat geld in ' $n$ land. Dit word daarom ook die grondwet genoem omdat geen ander wet wat gemaak word in botsing mag wees met die grondwet nie. As die grondwet byvoorbeeld vryheid van spraak waarborg, mag daar nie 'n wet gemaak word wat strydig is met die bepaling waarin vryheid van spraak gewaarborg word in die grondwet nie. Daar is ook so iets soos die grondwet van 
van 'n mens se lewe. Die inhoud van die grondwet van 'n mens se lewe word bepaal deur dit wat in sy hart omgaan in die taal van Spreuke 4:23.

Die wysheidsliteratuur help ' $n$ mens om beginsels te vind van waaruit geleef moet word. Spreuke 1:7 sê: "Kennis begin met die dien van die Here". Om in 'n verhouding met die Here te leef en om Hom te dien, om die Here te ken, is vir die Spreukedigter die basis van die kuns om te lewe. Die kuns om te lewe is die vermoë om die beste besluit te neem ooreenkomstig die orde wat God daargestel het. Dit is ook 'n faset van 'n tipies Ou-Testamentiese spiritualiteit. Volgens Loader (1986:103) is alle wysheid in wese religieus selfs waar dit alledaags en 'wêrelds' klink omdat die wysheidsleraars aanvaar dat God die instandhouer van die skeppingsorde is.

\section{Resultaat}

Dit is nie moontlik om tot finale gevolgtrekkings te kom binne die bestek van 'n artikel nie. Dit behoort egter duidelik te wees dat die Ou Testament wel 'n bydrae te lewer het tot die debat oor spiritualiteit en dat die bydrae van die $\mathrm{Ou}$ Testament nie die aandag gekry het wat dit verdien nie.

Hoogstens sou gesê kon word dat die bydrae tot die volgende hipoteses gelei het wat verder ondersoek kan word:

- Die tipiese van 'n Ou-Testamentiese spiritualiteit is ' $n$ lewe wat geleef word in die bewussyn van die teenwoordigheid van God.

- 'n Lewe in die teenwoordigheid van God word gestruktureer binne die verbond met sy appèl op gehoorsaamheid aan die Tora.

- God se teenwoordigheid is egter nie 'n probleemlose saak nie. Veral die profete wat verkondigers is van die Woord van die Here worstel met die skynbare onbetrokkenheid en dus afwesigheid van God in die geskiedenis en in hulle lewe.

- 'n Verwondering voor die misterie van God in sy (vir die mens) onbegryplikheid, is ook 'n aksent in 'n Ou-Testamentiese spiritualiteit.

- Gebed vorm die grondslag van 'n dialogiese verhouding met God en is 'n wesenlike deel van Ou-Testamentiese spiritualiteit.

- Die Wysheidsliteratuur bied 'n greep om die lewenskuns te bemeester vanuit die perspektief van 'n lewe in verhouding met God. 


\section{Bibliografie}

CHILDS, B S 1985 Old Testament theology in a canonical context London: SCM.

DAHOOD, M. 1974. Psalms I (1-50). New York: Double Day (Anchor Bible.)

DE JONGH VAN ARKEL, J.T. 1989 Spiritualiteit as semantiese struktuurkern: 'n pastorale perspektief. Praktiese Teologie in Suid-Afrika, 4(2):18-30

DEURLOO, K.D. \& DIEBNER, J. 1996. reds YHWY - Kyrios - Antitheism or the power of the Word. Festschrift fur Rochus Zuurmond anlasslich seiner Emiriterung am 26. Januar 1996. Heidelberg : DBAT

DIAMOND, A R 1987. The confessions of Jeremiah in context, scenes of prophetic drama Sheffield : JSOT Press (JSOT Suppl. Series 45.)

DU TOIT, A.B. 1993. Lewensgemeenskap met God as essensie van Bybelse spiritualiteit. Skrif en Kerk, 14(1):28-46

EICHRODT, W. 1975 Theology of the Old Testament, Vol I London : SCM.

HAAK, R.D 1992. Habakuk Leiden Brill.

ITTMANN, N 1981. Die Konfessionen Jeremias, Ihre Bedeutung für die Verkündigung des Propheten Neukirchen-Vluyn Neukirchener

JONKER, W.D 1989. Die eie-aard van gereformeerde spiritualiteit Nederduitse Gereformeerde Teologiese Tydskrif, 30(3):288-299

KLOPPERS, M.H.O 1988. Liefde uit dankbaarheid - 'n eksegetiese studie van Deuteronomium. (In Prinsloo, W.S. \& Vosloo, W reds. In mensetaal oor God se Woord. Huldigingsbundel opgedra aan prof. A.H van Zyl Kaapstad : Lux Verbi. p. 76-83.)

KRAUS, H.J 1972. Psalmen I. Neukirchen Neukirchener. (BKAT XV/1.)

LE ROUX, J H. 1986 . Tekste met 'n profetiese perspektief (In Deist, F.E. \& Vorster, W.S. reds Woorde wat ver kom. Die literatuur van die Ou Testament Deel l. Kaapstad : Tafelberg. p. 123-157.)

LOADER, J A. 1986 Tekste met 'n wysheidsperspektief. (In Deist, F.E. \& Vorster, W.S. reds. Woorde wat ver kom. Die literatuur van die Ou Testament Deel 1. Kaapstad : Tafelberg p 103-122.)

LOUW, D J. 1989. Spiritualiteit as Bybelse vroomheid in die teologie en die gemeentelike bediening Praktiese Teologie in Surd-Afrika, 4(2):1-17.

McKANE, W. 1977. Proverbs. A new approach London : SCM. (OTL.)

NICOL, W. 1989. Gereformeerde meditasie (In Theron, P.F \& Kinghorn, J. reds Koninkryk, kerk en kosmos Huldigingsbundel ter ere van prof. WD Jonker. Bloemfontein : Pro-Christo. p 48-63.)

ODENDAAL, D.H \& SMIT, D.J 1988 Psalm 42/43 (In Burger, C.W., Muller, B.A. \& Smit, D.J. reds. Riglyne vir prediking oor die Psalms Woord teen die Lig II/4. Kaapstad : NG Kerk-Uitgewers. p. 96-112)

PERDUE, L.G. 1994. Wisdom and creation The theology of Wisdom Literature. Nashville : Abingdon.

PIETERSE, HJ.C 1989. Tussen hemel en aarde Refleksies oor nuwe vorme van spiritualiteit Praktiese Teologie in Suid-Afrika, 4(2):48-56. 
PREUSS, H.D 1991. Theologie des Alten Testaments Band 1. JHWHIs erwahlendes und verplichtendes Handeln Stuttgart : Kohlhammer

PRINSLOOO, G.T.M 1989. 'n Literêr-eksegetiese analise van die boek llabakuk Pretoria UP. (D D -proefskrif.)

SIEBERT-HOMMES J. 1996. 'Ich werde sein' oder 'Ich werde da sein'. Eine Untersuchung zu Exodus 3, 14 (In Deurloo, K D \& Diebner, J. eds YHWY - Kyrios Antitheism or the power of the Word. Festschrift fur Rochus Zuurmond anlasslich seiner Emiriterung am 26. Januar 1996. Heidelberg : DBAT p. 59-67.)

SMIT, D.J. 1988 Wat is gereformeerde spiritualiteit? Nederdwitse Gereformeerde Teologiese Tydskrif, 29(2): 182-193.

SMIT, D.J. 1989. Kan spiritualiteit beskryf word? Nederduitse Gereformeerde Teologiese Tydskrif, 30(1):83-94, Jan

SNYMAN, S.D 1986. Die prediking van Psalm 42/43. Fax Theologica, 6(1) 45-52.

SNYMAN, S.D. 1996. 'n Struktureel-historiese eksegese van Habakuk 1:2-2:4a. Acta Theologica, 16(1);68-86.

STRAUSS, S.A. 1987. 'n Geheiligde lewe: Oefening in die toewyding aan God. Fax Theologica, 7(1):20-38.

THERON, J.P.J. 1989. Spiritualiteit en pneumatika: Konflik en aanvaarding binne gereformeerde kringe. Prakriese Teologie in Suid-Afrika, 4(2):31-47.

VON RAD, G. 1975a. Old Testament Theology, Vol I. London : SCM.

VON RAD, G. 1975b. Old Testament Theology, Vol. II. London : SCM.

VRIEZEN, Th. C. 1966. Hoofdlijnen der theologie van het Oude Testament Wageningen Veenman en Zonen.

WEISER, A. 1975. The Psalms. London : SCM. (OTL.)

ZIMMERLI, W. 1978. Old Testament theology in outline. Edinburgh : Clark. 
